\title{
Risiko Asfiksia pada Ketuban Pecah Dini di RSUP Sanglah
}

\author{
Wiradharma, Kardana I Md, Dharma Artana I Wyn \\ SMF/Bagian Ilmu Kesehatan Anak Fakultas Kedokteran Universitas Udayana RSUP Sanglah, Denpasar
}

Latar belakang. Ketuban pecah dini (KPD) merupakan salah satu faktor risiko terjadinya komplikasi persalinan. Semakin lama KPD, semakin besar kemungkinan terjadi komplikasi persalinan, sehingga meningkatkan risiko terjadi asfiksia.

Tujuan. Mengetahui besar risiko lama KPD terhadap kejadian asfiksia pada kehamilan cukup bulan.

Metode. Rancangan penelitian analitik kategorikal tidak berpasangan, dengan pendekatan kasus kontrol. Tujuhpuluh enam bayi yang dirawat di RSUP Sanglah, Denpasar periode bulan Mei-November 2010 dipilih secara consecutive. Bayi asfiksia 38 kasus dan sebagai kelompok kontrol 38 bayi tidak asfiksia. Lama KPD dikelompokkan menjadi $<12$ jam dan $\geq 12$ jam. Data lama KPD diambil dari catatan medik. Analisis data menggunakan uji Kai-kuadrat dan analisis multivariat (regresi logistik).

Hasil. Terdapat perbedaan bermakna antara lama KPD $(<12$ dengan $\geq 12)$ jam terhadap kejadian asfiksia ( $\mathrm{p}=0,002 ; \mathrm{RO}=8,0 ; \mathrm{IK} 95 \%$ 2,0-30,4).

Kesimpulan. Ketuban pecah dini merupakan faktor risiko terjadinya asfiksia.

Sari Pediatri 2013;14(5): 316-9.

Kata kunci: ketuban pecah dini, asfiksia

$\mathrm{K}$

etuban pecah dini (KPD) adalah selaput ketuban yang pecah sebelum adanya tanda persalinan. ${ }^{1}$ Insiden KPD di Indonesia berkisar $4,5 \%$ sampai $7,6 \%$ dari seluruh kehamilan, sedangkan di luar negeri insiden KPD antara 6\% sampai $12 \% .^{2}$ Asfiksia neonatorum

\section{Alamat korespondensi:}

Dr. I Made Kardana, SpA (K). Bagian/SMF Ilmu Kesehatan Anak Fakultas Kedokteran UNUD RSUP Sanglah Denpasar. Jl. P Nias, Telp./ Fax. (0361) 244038, Denpasar. adalah keadaan fetus atau bayi baru lahir, mengalami gangguan oksigen atau gangguan perfusi dari berbagai organ yang berhubungan dengan hipoksia jaringan dan asidosis. ${ }^{3}$ Derajat asfiksia ditentukan berdasarkan nilai Apgar. Nilai Apgar biasanya dinilai 1 menit setelah bayi lahir lengkap, selanjutnya dilakukan pada 5 menit berikutnya karena hal tersebut mempunyai korelasi yang erat dengan mortalitas dan morbiditas neonatal. ${ }^{4}$ Nilai Apgar menit pertama menunjukkan toleransi bayi terhadap proses kelahirannya, dan menit kelima menujukkan adaptasi bayi terhadap lingkungan barunya. ${ }^{5}$ Penelitian yang dilakukan di California 
mendapatkan insidens asfiksia pada bayi baru lahir sebesar 2\%-9\%. ${ }^{6}$

Ketuban pecah dini berkaitan dengan komplikasi persalinan, meliputi kelahiran kurang bulan, sindrom gawat napas, kompresi tali pusat, khorioamnionitis, abruption plasenta, sampai kematian janin yang meningkatkan mortalitas dan morbiditas perinatal. ${ }^{1,2,7,8}$ Semakin lama KPD, semakin besar kemungkinan komplikasi yang terjadi. ${ }^{1,7,8}$ Asfiksia dapat terjadi akibat kelahiran kurang bulan, sindrom gawat napas, gangguan plasenta maupun infeksi. ${ }^{1,27,8}$ Asfiksia yang terjadi pada bayi cukup bulan, seringkali diawali infeksi. ${ }^{7}$ Dari penelitian sebelumnya yang dilakukan oleh Nilufar dkk, ${ }^{9}$ didapatkan 33\% insiden terjadinya asfiksia pada KPD yang lama, berbeda secara signifikan dengan tanpa asfiksia $6,7 \%$.

Berdasarkan latar belakang KPD yang merupakan salah satu penyebab terjadinya asfiksia, maka perlu diketahui berapa lama kejadian KPD dapat menyebabkan terjadinya asfiksia. Penelitian kami bertujuan untuk mengetahui besar risiko lama KPD terhadap kejadian asfiksia pada kehamilan cukup bulan.

\section{Metode}

Penelitian analitik observasional dengan rancangan kasus kontrol dilakukan selama periode bulan Mei sampai November 2010, di ruang perawatan neonatus Bagian Ilmu Kesehatan Anak RSUP Sanglah, Denpasar. Kriteria inklusi adalah bayi asfiksia, usia kehamilan cukup bulan, persalinan berlangsung spontan/ tanpa tindakan (forsep, vakum ekstrasi, seksio sesarea). Kriteria eksklusi adalah bayi yang dilahirkan menderita kelainan bawaan, bayi mengalami intra-uterine growth retardation (IUGR), risiko infeksi, meliputi ibu febris, ibu tersangka infeksi saluran kencing, korioamnionitis dan ketuban hijau, dan data yang diperoleh kurang lengkap. Definisi operasional variabel asfiksia neonatorum adalah keadaan fetus atau bayi baru lahir mengalami gangguan oksigen, atau gangguan perfusi dari berbagai organ yang berhubungan dengan hipoksia jaringan dan asidosis. ${ }^{3}$ Asfiksia ditentukan berdasarkan nilai Apgar pada menit 1, dengan penilaian didasarkan pada Apgar $\geq 7$ (tidak asfiksia) dan Apgar $<7$ (asfiksia). ${ }^{7}$ Ketuban pecah dini adalah pecahnya selaput ketuban setiap saat sebelum terdapat tanda-tanda persalinan. Dibedakan menjadi dua yaitu $\mathrm{KPD}<12$ jam dan KPD $\geq 12$ jam.

Besar sampel berdasarkan kesalahan tipe I 5\%, kesalahan tipe II 20\%, nilai P2 dari penelitian Nili $\mathrm{dkk}^{10}$ diperoleh 0,7. Pada penelitian kami, RO (rasio odds) yang dianggap bermakna adalah 1,3. Berdasarkan perhitungan diperoleh $\mathrm{n} 1$ dan $\mathrm{n} 2$, yaitu masingmasing 38, jadi jumlah total sampel adalah 76 orang. Populasi adalah bayi asfiksia yang dirawat di RSUP Sanglah, Denpasar, sedangkan sampel diambil dari semua populasi yang memenuhi kriteria penelitian secara consecutive sampling. Faktor risiko asfiksia dikelompokkan berdasarkan kelompok risiko tinggi dan risiko rendah, mengalami asfiksia dari faktor ibu ataupun bayi. Risiko tinggi mengalami asfiksia, meliputi umur ibu $<18$ tahun atau $>35$ tahun, paritas 1 (primipara) atau $\geq 5$ (grand multipara), terdapat sakit, seperti asma, preeklamsi, eklamsi, gagal jantung dan riwayat obstetri buruk selama kehamilan, berat badan lahir $<2500$ gram atau $>4000$ gram, dan KPD $\geq 12$ jam. Bayi asfiksia dijadikan kasus, sedangkan kontrol adalah bayi tidak asfiksia, kemudian masing-masing subjek akan dilihat secara retrospektif, apakah ibu mengalami KPD $<12$ jam atau KPD $\geq 12$ jam. Data lama KPD diambil dari rekam medik. Data yang diperoleh disajikan dalam bentuk narasi, dianalisis dengan uji Kai-kuadrat, dan analisis multivariat (regresi logistik) dengan menggunakan komputer dengan tingkat kemaknaan $\alpha=0,05$ (IK95\%), serta dikatakan bermakna apabila $\mathrm{p}<0,05$.

Penelitian kami telah mendapatkan kelayakan etik dari Komisi Etik Penelitian Fakultas Kedokteran Universitas Udayana/Rumah Sakit Umum Pusat Sanglah Denpasar.

\section{Hasil}

Tujuhratus limabelas jumlah total persalinan selama bulan Mei-November 2010. Berdasarkan kriteria inklusi didapatkan 128 orang. Pasien yang dieksklusi 80 orang karena risiko infeksi (73), menderita kelainan bawaan (2), dan IUGR (5). Setelah ditambahkan kontrol sebesar 38 orang, jumlah total sampel 76 orang. Bayi asfiksia didapatkan pada umur ibu $>35$ tahun 2 sampel, paritas 1 (primipara) 21 sampel, paritas $\geq 5$ (grand multipara) 2 sampel, terdapat sakit, seperti asma, preeklamsi, eklamsi, gagal jantung atau riwayat obstetri buruk selama kehamilan 8 sampel, berat badan lahir 
$<2500$ gram 3 sampel, dan KPD $\geq 12$ jam 34 sampel. Karakteristik subjek pada kedua kelompok tertera pada Tabel 1.

Kami mendapatkan hubungan yang bermakna antara lama KPD dengan asfiksia. Rasio odds asfiksia pada KPD $\geq 12$ jam 9,7 kali dengan nilai p 0,004 (Tabel 2). Analisis multivariat dengan regresi logistik didapatkan tidak terdapat faktor risiko lain yang diteliti yang berbeda secara bermakna, selain faktor KPD seperti pada Tabel 3.

Tabel 1. Karakteristik sampel

\begin{tabular}{lll}
\hline Faktor risiko asfiksia & $\begin{array}{l}\text { Asfiksia } \\
(\mathrm{n}=38)\end{array}$ & $\begin{array}{l}\text { Tidak asfiksia } \\
(\mathrm{n}=38)\end{array}$ \\
\hline $\begin{array}{l}\text { Faktor ibu } \\
\text { Umur (tahun) }\end{array}$ & & \\
$\quad 18-35$ & & \\
$\quad>35$ & 36 & 36 \\
Paritas & 2 & 2 \\
$\quad 1$ & & \\
$2-4$ & 21 & 21 \\
$\quad \geq 5$ & 15 & 16 \\
Riwayat penyakit ibu & 2 & 1 \\
$\quad$ & & \\
$\quad$ Ada & 8 & 5 \\
Tidak ada & 30 & 33 \\
$\quad$ KPD (jam) & & \\
$\quad<12$ & 4 & 16 \\
$\quad \geq 12$ & 34 & 22 \\
Faktor bayi & & \\
Berat badan lahir (gram) & & \\
$\quad<2500$ & 3 & 2 \\
$\quad 2500-4000$ & 35 & 36 \\
\hline
\end{tabular}

Tabel 2. Rasio odds lama KPD dengan asfiksia

\begin{tabular}{ccccc}
\hline & $\begin{array}{c}\text { Asfiksia } \\
(\mathrm{n}=38)\end{array}$ & $\begin{array}{c}\text { Tidak asfiksia } \\
(\mathrm{n}=38)\end{array}$ & $\mathrm{RO}$ & $\mathrm{p}$ \\
\hline $\mathrm{KPD} \geq 12$ jam & 34 & 22 & 9,771 & $0,004^{*}$ \\
\hline
\end{tabular}

*Uji Kai-kuadrat; RO: rasio odds

Tabel 3. Analisis multivariat asfiksia dengan berbagai faktor risiko

\begin{tabular}{llll}
\hline Faktor penyebab asfiksia & $\mathrm{RO}$ & $\mathrm{IK} 95 \%$ & $\mathrm{p}$ \\
\hline Umur & 1,6 & $0,1-14,9$ & $0,6^{\#}$ \\
Paritas & 1,3 & $0,4-3,7$ & $0,6^{\#}$ \\
Riwayat penyakit ibu & 2,8 & $0,6-12,1$ & $0,1^{\#}$ \\
Berat badan lahir & 0,8 & $0,1-5,8$ & $0,8^{\#}$ \\
KPD & 8,0 & $2,0-30,4$ & $0,002^{\#}$ \\
\hline
\end{tabular}

\# Uji regresi logistik; IK: interval kepercayaan; RO; rasio odds

\section{Pembahasan}

Ketuban pecah dini merupakan masalah penting yang berkaitan dengan komplikasi, meliputi kelahiran kurang bulan, sindrom gawat napas, kompresi tali pusat, khorioamnionitis, abruptio plasenta, sampai kematian janin yang meningkatkan mortalitas dan morbiditas perinatal. ${ }^{1,3,7,8}$ Pasien yang mengalami ketuban pecah dini 50\%-75\% akan mengalami persalinan secara spontan dalam waktu 48 jam, 33\% akan mengalami sindrom gawat napas, 32\%-76\% mengalami kompresi tali pusat, 13\%-60\% mengalami khorioamnionitis, 4\%-12\% mengalami abruption plasenta, dan 1\%-2\% kemungkinan mengalami kematian janin. ${ }^{1,8}$ Semakin lama KPD, semakin besar kemungkinan komplikasi yang terjadi, sehingga meningkatkan risiko asfiksia. ${ }^{1,7,8}$

Ketuban pecah dini dapat mengakibatkan asfiksia, baik akibat kelahiran kurang bulan, sindrom gawat napas, gangguan plasenta maupun infeksi. 1,3,7,8 Terjadinya asfiksia seringkali diawali infeksi yang terjadi pada bayi, baik pada bayi cukup bulan terlebih lagi pada bayi kurang bulan, ${ }^{7}$ dengan infeksi keduanya saling mempengaruhi. ${ }^{1,7}$ Ketuban pecah dini dapat memudahkan infeksi asenden. Infeksi tersebut dapat berupa amnionitis dan korionitis atau gabungan keduanya disebut korioamnionitis. ${ }^{1,2,13}$ Selain itu korioamnionitis dapat dihubungkan dengan lama pecah selaput ketuban, jumlah kali periksa dalam dan pola kuman terutama grup Staphylococus. ${ }^{1,2}$ Sepsis awitan dini sering dihubungkan dengan infeksi intranatal, sedangkan sepsis awitan lambat sering dihubungkan dengan infeksi pascanatal terutama nosokomial.

Kami mendapatkan KPD $\geq 12$ jam dengan asfiksia $44,7 \%$, sedangkan $\mathrm{KPD}<12$ jam dengan asfiksia $5,3 \%$, dengan $\mathrm{RO}$ (rasio odds) 9,7 dan nilai $\mathrm{p}=0,004$, sehingga terdapat perbedaan yang bermakna antara lama KPD (<12 atau $\geq 12)$ jam terhadap asfiksia. Hasil tersebut sesuai dengan hasil penelitian yang dilakukan Halimah dkk, ${ }^{14}$ Setiyana, ${ }^{15}$ dan Fahrudin. ${ }^{16}$ Penelitian Halimah dkk mendapatkan 24 (63,15\%) bayi mengalami asfiksia neonatorum ketika terjadi KPD selama proses persalinan, yaitu 1 bayi $(2,63 \%)$ menderita asfiksia ringan, 8 bayi $(21,05 \%)$ menderita asfiksia sedang, dan 15 bayi $(39,47 \%)$ menderita asfiksia berat. Penelitian Setiyana mendapatkan KPD $>12$ meningkatkan risiko asfiksia neonatorum, dan penelitian Fahrudin mendapatkan berat badan lahir rendah, KPD, persalinan lama, tindakan seksio sesaria, 
riwayat obstetri yang jelek dan status perawatan prenatal yang buruk merupakan faktor risiko asfiksia neonatorum. Secara teori terdapat berbagai komplikasi pada bayi akibat KPD, antara lain persalinan kurang bulan, gawat janin, oligohidramnioan, penekanan tali pusat, sindrom gawat napas, serta risiko infeksi. ${ }^{1,8}$ Semakin lama KPD, maka semakin besar risiko komplikasi yang terjadi. Asfiksia dapat terjadi bisa akibat penekanan tali pusat, oligohidramnion, gawat janin, sindrom gawat napas maupun infeksi. Sehingga, semakin lama KPD maka komplikasi yang terjadi semakin besar, berakibat risiko terjadinya asfiksia pada janin, juga semakin meningkat. ${ }^{1,7}$

\section{Kesimpulan}

Berdasarkan hasil penelitian, KPD merupakan faktor risiko terjadinya asfiksia. Penelitian kami menggunakan data sekunder dari catatan rekam medik pasien. Disamping itu, variabel yang diteliti terbatas hanya beberapa variabel yang tersedia sehingga sangat memungkinkan terjadinya bias terhadap hasil penelitian. Untuk mencegah terjadinya asfiksia pada bayi, maka persalinan dengan KPD $\geq 12$ jam sebaiknya dilakukan di rumah sakit sehingga resusitasi bayi baru lahir dapat dilakukan secara optimal.

\section{Daftar pustaka}

1. Modena AB, Kaihura C, Fieni S. Prelabour rupture of the membranes: recent evidence. Acta Bio Medica Ateneo Parmense 2004;75:5-10.

2. Cammu H, Verlaenen H, Derde P. Premature Rupture of Membranes at Term in Nulliparous Women: A Hazard? Obstet Gynecol 1990;76:671-4.

3. Khan PA, Azam M, Malik FA. Birth Asphyxia; risk factors. The Professional 2004;2:416-24.
4. Onama C, Tumwine JK. Immediate Outcome of Babies With Low Apgar Score In Mulago Hospital, Uganda. East African Med J 2003;80:22-30.

5. Whelan MA. The Apgar Score. Pediatrics 2006; 118:1313-4.

6. Yvonne W, Kendall H, Shoujun Z, Heather J, Claiborne J. Declining Diagnosis of Birth Asphyxia in California: 1991-2000. Pediatrics 2004; 114:1584-90.

7. Khreisat W, Habahbeh Z. Risk Factors of Birth Asphyxia. Pak J Med Sci 2005;21:30-4.

8. Tanya M, Medina, Ashley H. Preterm Premature Rupture of Membranes: Diagnosis and Management. Am Fam Physician 2006;73:659-65.

9. Nilufar S, Nazmun N, Mollah A. Risk Factors and ShortTerm Outcome of Birth Asphyxiated Babies in Dhaka Medical College Hospital. Bangladesh J Child Health 2009;33:83-89.

10. Nili F, Shams A. Neonatal Complications of Premature Rupture of Membrane. Acta Medica Iranica 2003; 41:175-80.

11. Rehana M, Yasmeen M, Farrukh M, Naheed P, Uzma D. Risk Factors of Birth Asphyxia. J Ayub Med Coll Abbottabad 2007;19:67-71.

12. Shehla N, Ali F, Rubina B, Ruqqia S. Prevalence of PPROM and its Outcome. J Ayub Med Coll Abbottabad 2006;19:14-8.

13. Flenady V, King JF. Antibiotics for prelabour rupture of membranes at or near term (Review). The Cochrane Library 2009;2:1-22.

14. Halimah S, Candra D, Wisnubroto P. Hubungan Kejadian Ketuban Pecah Dini Pada Saat Persalinan Dengan Kejadian Asfiksia Bayi Baru Lahir (BBL). Diunduh 18 Oktober 2010. Didapat dari: URL:http://www.scribd.com/doc/15689407.

15. Setiyana A. Hubungan antara lama ketuban pecah dini terhadap nilai APGAR pada kehamilan aterm di badan rumah sakit daerah Cepu (Tesis). Surakarta: FKUMS, 2009.

16. Fahrudin. Analisis beberapa faktor risiko kejadian asfiksia neonatorum di kabupaten Purworejo (Tesis). Semarang: MIKMUNDIP, 2003. 